\title{
Views of Nigerian Teachers on Strategies for Curbing Indiscipline: Implications for Counselling Practices
}

\author{
Adeola Aminat Odebode \\ Counsellor Education, University of llorin, Nigeria \\ 凶 odebode.aa@unilorin.edu.ng
}

\begin{abstract}
This study investigated the strategies for curbing indiscipline in elementary school teachers in Nigeria. It also examined the influence of gender, years in service and educational qualification on the respondents' expressions. This study employed a descriptive analysis of 200 elementary school teachers as participants. An instrument to analyze the data was developed, named "Strategies for Curbing Indiscipline Questionnaire" (SCIQ). The psychometric properties of the instrument were developed. Data were analyzed with both descriptive and inferential statistics. The result showed that the use of the approach to promote acceptable behaviours considered successful. As the result, school authorities being good models, giving moral education in schools, adopting behavioural such as punishment, high parental supervision and referral to appropriate helping personnel are some of the strategies that could be used to curb indiscipline among students. It is, therefore, recommended that behaviour modification strategies should be adopted to curb indiscipline among students.
\end{abstract}

Keywords: Curb, strategies, indiscipline, Nigeria, teachers.

How to Cite: Odebode, A. (2020). Views of Nigerian Teachers on Strategies for Curbing Indiscipline: Implications for Counselling Practices. Mimbar Sekolah Dasar, 7(1), 30-42. doi:https://doi.org/10.17509/mimbar-sd.v7i1.23477.

INTRODUCTION Youths are the future leaders of any nation; they form the major tool for driving the growth of any nation. However, the incidence of indiscipline has been a burden for parents, educators, administrators and the entire public. Therefore, for meaningful and long lasting development of any society, the youth would not only be nurtured but also be of good morals. Indiscipline is a maladaptive behavior that is categorized under delinquency; it is usually the basis of many psychological damages. A child who is not disciplined is an unruly, ungovernable child that can cause any disruption to the peace of the society (Canter \& Canter, 2001).

It has been documented that indiscipline among students is caused by lack of teaching aids/materials in school, peer influence, family, society, society, poor leadership, lack of justice and realistic regulations (Canter \& Canter, 2001). Parental influence, teacher influence, political, social and economic factors cause indiscipline among students (Moronguwa, 2010). Furthermore, Trunners (2009) and Odebode (2019) submitted that indiscipline has been caused by various factors emanating from the idea of democracy with strong emphasis on the right of individuals; the gap between the young and old; the increase in technological development and the influence of media. 
Adeola Aminat Odebode, Views of Nigerian Teachers on Strategies for Curbing Indiscipline...

Indiscipline refers to one's inability to adhere to laid down rules in any establishment or society. It is an act of lack of self-control, disrespect for dos and don'ts of any society (Strauss, 2001; Odebode 2019). Indiscipline among students refers to these students not conforming to school regulations. This could manifest in the area of not putting on the appropriate uniform, lateness to school, disrespecting school authorities, stealing, verbal and physical aggression, lateness, truancy, smoking, and drinking among others. Over the last decades, indiscipline among students remains the order of the day (Asiyai, 2012). Indiscipline among students refers to these students not confusing to school regulation. This could manifest in the area of not putting on the appropriate uniform, lateness to school, disrespecting school authorities, stealing, verbal and verbal and physical aggression, truancy, smoking and drinking among others (Freire \& Amado, 2009). Indiscipline can also occur as students talking while the teacher is teaching, stealing, involvement in examination practices, truancy, leaving school without seeking due permission.

Indiscipline has many faces; its manifestations, causes and effects in the social and educational fields (Ali, Dada, Isiaka \& Salaman, 2014). One heartbreaking issue that the world is fighting against is issue of indiscipline among youth (Aguba, 2009; Danso, 2010; Ngwokabuenui, 2015; Odebode, 2019; Reid, 2000;). The school system which is rated as a medium for transformation of individuals' lives and to impart knowledge, skills and values is colored with students' indiscipline. Deaukee (2010) concluded in a study that the zerotolerance strategy for curbing indiscipline has no significant effect. Teachers and parents are expressing frustration at the number of incidence of indiscipline that happens on daily basis. The present state of indiscipline among students is disturbing and requires spontaneous reaction to curb.

Curbing indiscipline among students could take different dimensions such as referring the unruly students to disciplinary committee, application of corporal punishment, verbal condemnation, reinforcement, referring for counselling and organizing talks (Hezekiah \& Nkechi, 2005). Simatwa (2012) explained that indiscipline among students can be curbed through entrusting lots of responsibilities on students such as making them school prefect, supervisors etc., helping students to make use of their pool of energy to acts that can benefit them, discipline among all school staff, making youths engaged in recreational activities, improving on methods of teaching, giving moral education to mention a few.

Oosthuizen, Roux and Van der Walt (2003) believed that through organizing guidance programmes for students, giving mentoring to students, helping students to acquire life skills and educating them on the causes and consequences of indiscipline could put a stop to indiscipline. Paul (2009) also aligned with behaviorists that through the use of reward and punishment can be adopted in curbing indiscipline. Christine and Daniel (2016) stated that 
students should be involved in school recreational program to curb indiscipline. They should be made to engage in co-curricular activities to channel their attention and energy away from indiscipline. In spite of all these submissions, indiscipline is still high among students. It is on this basis that this study was conducted.

\section{THEORETICAL BASIS FOR THE STUDY}

\section{Kounin Theory}

Kounin is a renowned contributor of behavioral method and approach which is based on the action-response of the behaviorist theories. Kounin (1971) explained that students imbibe acceptable behaviors and drop unacceptable ones with the aim of gaining reward in form of acceptance, praise, acknowledgement and avoiding punishment of any kind. When reward follows a behavior, such behavior is strengthened and there is every tendency that such behavior will be exhibited over and over again. However, when unacceptable response is presented with pain and fear, such behavior is weakened and may never be exhibited (Allen, 1999). Skinner centered on controlling learner's behavior and achieving behavior change. Kounin focused on educator's behavior to achieve acceptable and eradicate maladaptive behavior of students. This means that according to Kounin's model that the teachers have the responsibility of making the learners/students behave in acceptable ways.

Kounin adopted systematic and scientific method of assessing indiscipline among students; he explained lesson and management strategies to curb indiscipline. Kounin opined two methods that can be adopted in enhancing students' acceptable and desirable behavior: (1) whithitness (2) overlapping. By whithitness, Kounin means that the teacher must have "an eye at the back of his head' to see what goes on in the class even when he/she is not there. The teacher must be able to see, observe and infer what goes on behind them at all time. Overlapping implies that the teacher should be able to attend to two things at a time e.g. a teacher could be marking students' classwork, he also should be able to pay attention to the actions of the students in class. By implication, in the school, while the school administrators are in their offices attending to files and other issues, they should have an eye at the back of their head to know what goes on among students. Similarly, they should be able to overlap their actions by ensuring discipline among students while they also attend to other school issues (Charles, 1996). Same goes for class teachers. This way, Kounin believed students can be monitored, paid attention to; teachers can also note when students engage in unruly behaviors. The educators will be able to appropriately reduce acts of indiscipline while acceptable behaviors can be rewarded to strengthen such behavior as at when due. He made use of teacher-methods that keep the students busy in lesson which resultantly reduces unacceptable behavior. This teaching has considerable impact on maintaining discipline. This is done by keeping the students busy and paying attention to them at the same time. The 
Adeola Aminat Odebode, Views of Nigerian Teachers on Strategies for Curbing Indiscipline...

implication of this theory is that the school, school administrators and teachers can make a great impact in curbing indiscipline among students and youths at large using suitable measures.

\section{Statement of the Problem}

Over the last two decades, indiscipline among students remains the order of the day. It has become a norm among student in Nigeria; students engage in all sort of unruly behavior such as stealing, fighting, disruption of society peace to mention a few. The resultant of indiscipline is manifesting in high pace with many young people falling prey. Young people now misbehave which disrupt peace and smooth running of the school and society. Many efforts had been put forward to curb indiscipline to no avail. Many research have also been conducted on curbing indiscipline such as that of Ali, Dada, Isiaka and Salman (2014), Asiya (2012), Bhan and Gupta (2010) and Freire and Amado (2009) among other researches. It is sad that the indiscipline has not been curbed rather; it continues to rise in the Nigerian society. Many of these studies either centered on the triggers of indiscipline or its patterns; many of these studies were also conducted in other parts of the world. These put together created a research gap for this study to fill. Therefore, this study focused on the views of Nigerian teachers on the strategies for curbing indiscipline with moderating variables like gender, length of service and educational level. It also led to the question that what are the views of Nigerian teachers on the strategies for curbing indiscipline? Similarly, the following hypotheses were formulated and tested in this research:

1. No significant difference exists in the Nigerian teachers' views on strategies for curbing indiscipline on the basis of gender.

2. No significant difference exists in the Nigerian teachers' views on strategies for curbing indiscipline on the basis of length of service.

3. No significant difference exists in the Nigerian teachers' views on strategies for curbing indiscipline on the basis of educational level.

\section{METHOD}

\section{Design}

This study was conducted between March and August, 2018. For the fact that this research examined the views of Nigerian teachers on the strategies for curbing indiscipline, it is descriptive in nature; therefore, the descriptive research survey was employed. This survey is appropriate for a study which aimed at describing certain phenomenon in a factual manner; it is usually done with the use of interview, observation or/and questionnaire (Ali, 2006; Sharma, 2008). In this study, the questionnaire was adopted as the instrument to describe the strategies for curbing indiscipline. 


\section{Procedures for Sampling the Participants}

Nigerian teachers formed the population for this study and this included all elementary school teachers in Nigeria. However, the target population in which sample was drawn consisted of elementary school teachers in Ilorin, Kwara State, Nigeria with a total of 18, 255 (Kwara Annual Education Sector Performance Report, 2010). To select sample, the Researcher Advisor (2006) was used. At 95\% confidence and 2.5 margin of error, and $5 \%$ of nonresponse, a sample size of 400 was arrived at. The purposive sampling procedure was employed to purposely choose 20 densely populated elementary schools in llorin. The simple random sampling technique was afterwards employed to select 20 participants from the earlier selected schools. This was done by writing the names of the teachers in those schools on sheets of papers, folded them and placed them in a hat. The researchers picked 20 names from this procedure and these participants were selected to partake in the research. This procedure amounted to a total of 400 elementary school teachers that were selected for the research.

\section{Instrumentation}

For this research, a researcher-structured questionnaire titled "Strategies for Curbing Indiscipline Questionnaire ( $S C I Q$ ) was employed to gather the needed information. The items in the questionnaire were developed through review of relevant literature. The instrument consisted of two parts; I and II. Part I centered on the demographic information of the participants, part II has fifteen items on the strategies for curbing indiscipline. According to Ali (2006), a structured questionnaire can be employed to collect data for a descriptive survey research.

Validity: that an instrument adequately assesses what it was designed to assess means the instrument has validity (Stangor, 2004). SCIQ merited this quality by giving copies to five academics that have the expertise for checking the validity of any instrument. These experts vetted and modified some items to suit the its purpose. The corrections made on the instrument were effected and the final draft of SCIQ was adjudged valid for this research.

Reliability: to adjudge that an instrument is reliable, the instrument must have measured consistently over a certain period of administration. The reliability of SCIQ was ascertained through the test re-test reliability procedure. The researchers administered SCIQ twice on 20 teachers in Upper Basic Education in Ilorin metropolis at an interval of three weeks. These sets of scores generated were subjected to analysis using Pearson's Product Moment Correlation statistics; this produced a correlation co-efficient of 0.71 . Therefore, it was concluded that $S C I Q$ was reliable as an instrument for this research.

\section{Scoring Procedure of the Instrument}


Part I which elicited demographic information was scored using percentage. Part II which elicited information on strategies for curbing indiscipline was scored through the assignment of scores to each response. This indicates that for any response of Strongly Agree, 4 points is assigned; Agree, 3 points is assigned; Disagree, 2 points is assigned and Strongly Disagree, 1 point is assigned. Thus, the mean score that any item will have is 2.50 . This further showed that an item could either be scored between 1 and 4 with 2.5 as the bench mark for making decision. Any ltem with 2.5 and above was regard as the strategies that can be employed for curbing indiscipline in schools while items scored below 2.5 were not regarded among the strategies that can be adopted.

\section{Procedures for Administering the Instrument and Collection of Data}

SCIQ was distributed to the respondents who were willing to participate in the study. This was done with the support of some research assistants that were well informed on the necessity of the administration. The participants were also briefed appropriately on the administration and were given enough time to respond to SCIQ. The researchers and the research assistants collected the questionnaire back on the spot to ensure $100 \%$ retrieval rate.

\section{Method of Data Analysis}

Part I of SCIQ was analyzed using percentage while, part II was analyzed using t-test and Analysis of Variance and decision made at 0.05 alpha level.

\section{RESULTS}

\section{Demographics}

This section provides the analysis of the information gathered on demographics of the participants.

Table 1: Demographics of the Respondents: Gender, Length of Service and Educational Level

\begin{tabular}{|c|c|c|c|}
\hline$\overline{S / N}$ & Demographics & Frequency & Percentage\% \\
\hline \multirow[t]{4}{*}{1.} & Gender & & \\
\hline & Male & 164 & 41.0 \\
\hline & Female & 236 & 59.0 \\
\hline & Total & 400 & 100.0 \\
\hline \multirow[t]{5}{*}{2.} & Length of Service & & \\
\hline & $1-5$ years & 156 & 39.0 \\
\hline & $6-10$ years & 244 & 61.0 \\
\hline & 11 years \& Above & - & - \\
\hline & Total & 400 & 100.0 \\
\hline \multirow[t]{5}{*}{3.} & Educational Level & & \\
\hline & Grade II/NCE & 72 & 18.0 \\
\hline & B.Ed. & 308 & 77.0 \\
\hline & M.Ed. \& Above & 20 & 5.0 \\
\hline & Total & 400 & 100.0 \\
\hline
\end{tabular}

Source: Author's Computation 
This Table shows the demographic information of the participants through gender, length of service and educational level. The table shows that 400 teachers participated in this research, in which 164 (41.0\%) were men and 236 (59.0\%) were women. Also, 156 (39.0\%) of the have spent 1 to 5 years in service and $244(61.0 \%)$ of the participants have spent between 6-10 years in service. Similarly, $72(18.0 \%)$ of the participants have Teacher Training/NCE educational qualification, 308 (77.0\%) have B.Ed. educational qualification while, 20 (5.0\%) have Master's educational degree and beyond.

The table below provided answer to the question raised that: What are the views of Nigerian teachers on the strategies for curbing indiscipline?

Table 2: Rank Order of Nigerian Teachers' Views on Strategies for Curbing Indiscipline

\begin{tabular}{|c|c|c|c|}
\hline \multicolumn{2}{|c|}{ Item No. } & \multirow{2}{*}{$\begin{array}{c}\text { Mean } \\
3.60\end{array}$} & \multirow{2}{*}{$\begin{array}{l}\text { Rank } \\
1\end{array}$} \\
\hline 12 & use of reinforcements to promote acceptable behavior & & \\
\hline 2 & school authorities being good models & 3.59 & 2 \\
\hline 1 & giving moral education in schools & 3.58 & 3 \\
\hline 10 & adopting punishment & 3.51 & 4 \\
\hline 14 & facilitating war against indiscipline in school & 3.49 & 5 \\
\hline 11 & provision of counselling services & 3.47 & 6 \\
\hline 3 & involvement of students in making rules and regulations & 3.44 & 7 \\
\hline 8 & functional Parents-Teachers Association & 3.34 & 8 \\
\hline 7 & ensuring value re-orientation & 3.31 & 9 \\
\hline 13 & application of culture and tradition in teaching students & 3.30 & 10 \\
\hline 6 & reduction of class size & 3.25 & 11 \\
\hline 9 & emphasis on extracurricular activities & 3.20 & 12 \\
\hline 5 & enforceable rules and regulations & 3.19 & 13 \\
\hline 4 & high parental supervision & 3.16 & 14 \\
\hline 15 & referral to appropriate helping personnel such as counsellor & 3.05 & 15 \\
\hline
\end{tabular}

Source: Author's Computation

This Table presents the rank order and means of views of Nigerian teachers on the strategies for curbing indiscipline. It can be seen on the table that all the items are above 2.5; it is therefore judged that from the views of Nigerian teachers, the strategies for curbing indiscipline are use of reinforcements to promote acceptable behaviors, school authorities being good models, giving moral education in schools, adopting behavioral such as punishment, high parental supervision and referral to appropriate helping personnel, such as counselor etc.

\section{Testing of Hypotheses}

The hypotheses postulated were tested using t-test and ANOVA statistical tools at 0.05 alpha level. 
Adeola Aminat Odebode, Views of Nigerian Teachers on Strategies for Curbing Indiscipline...

One:

No significant difference exists in the Nigerian teachers' views on strategies for curbing indiscipline on the basis of gender.

Table 3: Data Analysis using t-value to show the Strategies for Curbing Indiscipline on the basis of Gender

\begin{tabular}{llccccc}
\hline Gender & N & Mean & SD & df & Cal. t-value & Crit. t-value \\
\hline Male & 164 & 50.60 & 5.30 & 198 & $2.28^{*}$ & 1.96 \\
Female & 236 & 50.44 & 3.93 & & & \\
\hline
\end{tabular}

Source: Author's Computation

$* P<0.05$

This Table indicates that the critical t-value of 1.96 is less that the calculated t-value of 2.28. This shows that a significant difference exists in the Nigerian teachers' views on strategies for curbing indiscipline on the basis of gender thus, the hypothesis is not accepted.

Two:

No significant difference exists in the Nigerian teachers' views on strategies for curbing indiscipline on the basis of length of service.

Table 4: Data Analysis using t-value to show the Strategies for Curbing Indiscipline on the basis on Length of Service

\begin{tabular}{lllllcc}
\hline Years & $\mathbf{N}$ & Mean & SD & df & Cal. t-value & Crit. t-value \\
\hline 1-5 years & 156 & 49.12 & 4.22 & 198 & $3.60^{*}$ & 1.96 \\
6-10 years & 244 & 51.39 & 4.51 & & & \\
\hline
\end{tabular}

Source: Author's Computation

${ }^{*} \mathrm{P}<0.05$

This Table indicates that the critical t-value of 1.96 is less that the calculated t-value of 3.60 .

This shows that a significant difference exists in the Nigerian teachers' views on strategies for curbing indiscipline on the basis of length of service thus, the hypothesis is not accepted.

\section{Three:}

No significant difference exists in the Nigerian teachers' views on strategies for curbing indiscipline on the basis of educational level.

Table 5: ANOVA showing the difference of the Respondents' Views on Strategies for Curbing Indiscipline on the basis of Educational Level

\begin{tabular}{llccllll}
\hline $\begin{array}{l}\text { Educational } \\
\text { Level }\end{array}$ & SS & df & MS & $\begin{array}{l}\text { Cal. } \\
\text { F-ratio }\end{array}$ & $\begin{array}{l}\text { Crit. } \\
\text { F-ratio }\end{array}$ & p-value & Decision \\
\hline $\begin{array}{l}\text { Between group } \\
\text { Within group }\end{array}$ & 68.030 & 2 & 34.01 & 1.92 & 3.00 & 0.00 & Significant \\
\hline
\end{tabular}


Source: Author's Computation

This Table reveals that the critical f-ratio of 3.00 is greater than the calculated f-ratio of 1.92 . This shows that no significant difference exists in the Nigerian teachers' views on strategies for curbing indiscipline on the basis of educational level thus, the hypothesis is accepted.

\section{DISCUSSION}

In this research, results revealed that the Nigerian teachers' views on strategies for curbing indiscipline are use of reinforcements to promote acceptable behaviors, school authorities being good models, giving moral education in schools, adopting behavioral such as punishment, high parental supervision and referral to appropriate helping personnel, such as counselor etc. this implies that secondary students are willing and hope that indiscipline can be curbed if these and many more strategies are adopted. The finding of this study tallies with that of Simatwa (2012); Christine and Daniel (2016); Paul (2009) and Oosthuizen, Roux and Van der Walt (2003) whose findings revealed that through organizing guidance programmes for students, giving mentoring to students, helping students to acquire life skills, educating students on the causes and consequences of indiscipline, use of reward and punishment can be adopted in curbing indiscipline, students' involvement in school recreational program, indiscipline among students can be curbed. The finding of this could be that indiscipline has taken its toll on students which is eroding the moral standards in the society and this can be easily observed and expressed by Nigerian teachers.

The finding of this research also revealed that a significant difference existed in the Nigerian teachers' views on strategies for curbing indiscipline on the basis of gender. This implies that gender has an influence in the views of Nigerian teachers on strategies for curbing indiscipline. It also means that the way male elementary school teachers expressed strategies of curbing indiscipline differed from the way female elementary school teachers did. The result also revealed that males had a higher mean than females, which means that male elementary school teachers expressed the strategies for curbing indiscipline more than female teachers did. This finding tally with that of Trunners (2009) and Ada (2010) whose findings showed that gender can influence the respondents' expression on strategies for curbing indiscipline in schools. The direction of the result of this research could be because of the way men perceive issues which is more critical than that of women. This could also be that many men are usually very strict when it comes to disciplinary matters than many women.

The finding of this research showed that a significant difference existed in the Nigerian teachers' views on strategies for curbing indiscipline on the basis of length of service. This 
Adeola Aminat Odebode, Views of Nigerian Teachers on Strategies for Curbing Indiscipline...

means that the length of years that elementary school teachers have spent in school influenced their expressions on strategies for curbing indiscipline. The finding also showed that Nigerian teachers that have spent 6 years and above in service expressed the strategies more than those that have spent between 1-5 years in service. This finding is in line with that of Adams (2000) and Canter and Canter (2001) whose study showed that length of years in service affects teachers' expressions on the strategies for curbing indiscipline. This finding could be as a result of the fact that teachers that have spent 6 years and above in service have been dealing with students and have more experience on disciplinary issues than teachers who have spent lesser years in service. Therefore, their views on strategies for curbing indiscipline in schools will be different.

The finding of this study revealed that no significant difference existed in the Nigerian teachers' views on strategies for curbing indiscipline on the basis of educational level. This means whether teachers are highly educated or not, they did not express the strategies for curbing indiscipline differently. This finding is in support of the findings of Kiprop (2012) and Oosthuizen, Roux and Van der Walt (2003) which revealed that the higher the educational qualification of respondents, the more they are better able to express their opinions on the issue at hand. This could be because these teachers are all educated and are exposed to the enormity of indiscipline in schools hence; it is their wish that this menace be curbed.

\section{CONCLUSION}

The use of reinforcements to promote acceptable behaviors, school authorities being good models, giving moral education in schools, adopting behavioral such as punishment, high parental supervision and referral to appropriate helping personnel, such as counselors etc are strategies for curbing indiscipline among students. Furthermore, significant differences existed in the Nigerian teachers' views on strategies for curbing indiscipline on the bases of gender and length of service but no significant difference existed based on educational level.

\section{IMPLICATIONS OF THE FINDINGS TO COUNSELLING PRACTICES}

The finding of this research revealed that the Nigerian teachers' views on strategies for curbing indiscipline are: use of reinforcements to promote acceptable behaviors, school authorities being good models among others therefore, counsellors must however ensure that they liaise with school authorities to make use of reinforcement to motivate students to be disciplined; school authorities stand and serve as good role models for their students to emulate as students the behaviors of authority figures; orientate parents to supervise their children highly as supervision will go a long way in reducing and curbing indiscipline among 
students; encourage parents and school authority to refer students who are exhibiting undisciplined behavior for appropriate counselling.

\section{RECOMMENDATIONS}

These recommendations stemmed from the findings of this research:

1. Teachers and parents should adopt behavioral modification strategies such as reinforcement to promote good behaviors of secondary school students. It has been noted that when people are praised for doing good, there is every tendency that they continue the virtuous deeds; this will curb indiscipline.

2. Teachers and other non-teaching staff should be of good behaviors so as to be role models to students. Students observe and emulate from elders, teachers and other eminent figures around them. To this end, all school staff must be of good moral standing to lead their students aright and serve as a point of good reference.

3. Moral education must be continually given in schools and at home. This will serve as eye opener for students to the danger of indiscipline as well as the benefit of being of good conduct.

4. Appropriate and commensurate punishment should be melted out to stubborn students. This should however, be used sparingly and only when all other behavioral modification strategies have failed.

5. Counseling services must be provided in schools continuously. This could be done in form of orientation at all-time which will stand as preventive and curative counselling. Counsellors should co-opt all other staff members to ensure that this is achieved in schools.

\section{ACKNOWLEDGEMENTS}

The researchers thank the participants of this study for their cooperation. Similarly, the researchers are thankful to the research assistants who helped in the collection of data.

\section{REFERENCES}

Adams, A. T. (2000). The status of school discipline and violence. Annals of the American Academy of Political and Social Science, 567, 140-156.

Allen, T. H. (1999). Developing a discipline plan for you. Retrieved on 8th April, 2019 from http://www.humboldt.edu/ thal/discip-options.html.

Ali, F. (2006). Ensuring reliable data survey studies through research. Retrieved on $15_{\text {th }}$ March, 2018 from https://www.researchgate.net/surveystudiesaccurate/ensuringreliabledata. 
Adeola Aminat Odebode, Views of Nigerian Teachers on Strategies for Curbing Indiscipline...

Ali, A. A., Dada, I. T., Isiaka, G. A., \& Salaman, S. A. (2014). Types, causes and management of in disciplinary acts among secondary school students in Shomolu Local Government Area of Lagos State. Journal of Studies in Social Science, 8(2), 254-287.

Aguba, C. R.(2009). Educational administration \& management: Issues \& perspectives. Enugu: Ton and Tons PDS.

Asiyai, R. I. (2012). Indiscipline in Nigerian secondary schools: types, causes and possible solution. African Journal of Education and Technology, 2(1), 39-47.

Bhan, K. S., \& Gupta, R. (2010). Causes and Management of indiscipline among secondary students in Ojo Local Government Area of Lagos State. Journal of Applied Research in Education, 15(1), 1-9.

Charles, C. M. (1996). Building classroom discipline (5th ed.). New York: Longman.

Canter, L., \& M. Canter. (2001). Assertive discipline: Positive behavior management for today's classrooms. 3rd ed. Seal Beach, CA: Canter.

Christine, A., \& Daniel, D. (2016). Dilemma of indiscipline in Secondary Schools: A case study of Toro Local Government Area Plateau State Nigeria, Implications for Corruption and Terrorism. British Journal of Education, 4(10), 85-99.

Danso, S.K. A. (2010). Uni Don worries about indiscipline in schools. Available at http://www.newmyjoyonline.com/education/2010-07

Deaukee, L. (2010). Students' perceptions of indiscipline at three primary schools in one Educational District in Central Trinidad. An unpublished M.Ed Thesis, University of the West Indies.

Freire, I. \& Amado, J. (2009). Managing and handling indiscipline in schools. International Journal of Violence and School, 8, 85-97.

Hezekiah, O. A., \& Nkechi, O. (2015). Strategies for managing indiscipline among secondary school students in Nigeria. International Journal of Educational Foundations \& Management, 9(1), 23-33.

Kiprop, C. J. (2012). Approaches to management of discipline in secondary schools in Kenya. International Journal of Research in Management, 2(3), 120-138.

Kounin, J. (1977). Discipline and group management in classrooms. New York: Holt, Rinehart, and Winston.

Moronguwa, C. M. (2010). The impact of disciplinary problems on educator

morale in secondary schools and implications for management. An unpublished M. Ed. Thesis, University of Nigeria, Nsukka.

Ngwokabuenui, P. Y. (2015). Students'indiscipline: types, causes and possible solutions: the case of secondary schools in Cameroon. Journal of Education and Practice, 6(22), 64.

Odebode, A. A. (2019). Causes of indiscipline among students as viewed by primary school teachers in Nigeria. Mimbar Sekolah Dasar, 6(1), 126-140.

Oosthuizen, I.J. Roux, J.M. \& Van der Walt, J.L. (2003). A Classical Approach to the restoration of Discipline in South African Schools.. Koers 68: $373-390$

Reid, K. (2000). Tackling truancy in schools: practical manual for primary and secondary schools. UK: Routledge.

Research Advisor (2006). Table for sample size. Available at https://www./samplesizeable.

Sharma, R. A. (2008). Educational research. R.Lall Book Depot, Meerut, 209. 
Simatwa, E. M. W. (2012). Management of student discipline in secondary schools in Kenya, a case study of Bungoma County. Educational Research, 3(2), 172-189.

Strauss, M. A. (2001). Beating the devil out of them: Corporal punishment in American families. New Brunswick, NJ. Transaction Publishing.

Trunners, B. (2002). Discipline in Schools. World Educational Publication. Journal of Studies in Social Sciences, 287, 12-34. 